Academic Entrepreneurship for Medical and Health Scientists

\title{
Company Formation Checklist/Operating Partnership Agreement Questionnaire
}

Published on: May 24, 2021

License: Creative Commons Attribution 4.0 International License (CC-BY 4.0). 


\section{Overview}

This document is a useful initial step in the process of company formation and should be completed prior to preparing a Founder's Agreement (aka Operating/Partnership Agreement)

\section{Business}

- A. Briefly describe nature of business.

- B. Is it existing or start-up.

- a. If entity already existing, then:

- i. Contribution of each member to date:

- ii. Does existing equity structure fairly reflect each member's contributions to date? If not,

- 1. Describe adjustments that need to be made.

- C. Briefly describe the vision each member has for the future of the entity.

- a. What will each member contribute to operating and building the business.

- b. How is business going to generate money for the members? (Circle all that apply)

- i. Providing jobs for members.ii.Paying annual profits to members.

- iii. Building a business that can be sold at a later date.

- D. What is the length of time each member plans to be involved in operating the business?

- E. What is the length of time each member plans to be involved in the business as a member?

- F. What are members plans for ultimate disposition of business?

$\circ$ a. Sale? If so,

- i. When?

- ii. To whom?

- b. Dissolution/Wind-up?

- c. Pass on to children or other family members?

- G. Any business plan? If so, please provide copy.

$\circ$ a. If not,

- i. Why?

- ii. When will there be one? 


\section{Members}

- A. Names, addresses, and telephone numbers:

- B. Ownership interests of each member.

- a. Number or percentage of membership units owned by each member.

- b. Number of votes each member will have.

- e.g., one unit, one vote or some other formula.

- C. Briefly describe what each member perceives as the key issues related to operating and building the business:

The start of the company needs to preserve and enhance its strong, credible foundation.

"A startup messed up at its foundation cannot be fixed."

Misalignment among vision, ownership, control, and those working in the company

Managing complexity-need for clear, direct, excellent leadership to manage technology, science and business-and making sure that all are done well. Also, making sure that alignment is achieved between founders, employees, and early investors

Find sufficient funding or make customer-informed strategic compromises to launch an excellent product

Finding the right balance:

- between investment in the technology and compensation

- balance between critical contributions, salary and equity

- balance between execution and innovation

First capital raise: Finding the correct initial investors-value the vision and have the resources

First hires: Find and retain the best staff, consultants and vendors with the appropriate incentives and the correct salaries for these hires-if there is a salary-heavy company, there is no room for course correction and the salaries will be driven by that of the CEO-we should think more about equity than salaryHow to appropriately vest equity over time

Make promises/contracts that are consistent with our resources and vision to maintain the highest quality and credible reputation 
- D. Will there be loans by members to company? If so,

- a. What will be the terms of the loans?

- E. Membership Units to be owned by each member:

- a. Attributed price of each membership unit:

- b.Amount paid or to be paid for membership units held by each member:

- i.Have all membership units been fully paid for by each member? If not,

- 1.Number of membership units yet to be paid for:

- 2.When will payment be made?

- F. Has each member consulted with his/her attorney or accountant regarding tax consequences of their ownership of the membership units?

\section{Officers}

- A. Number:

- B. How selected?

- C. Titles (e.g., chairman of the board, president, vice-president, secretary) and Names:

- a. Job descriptions.

- b. Who reports to whom?

\section{Financing}

- A. Amount of money or thing(s) of value each member is contributing to company:

- B. Are contributions to be loans or equity?

- C. If loans, are they to bear interest?

- a. If so, interest rate:

- b. Period of repayment.

- D. Are loans to be secured?

$\circ$ a. By what?

- E. Repayment terms of loans:

- F. Any third party financing?

- a. Source:

- b. Amount:

- c. Anticipated terms:

- G. What if more money is needed to finance company?

- a. How will such decision be made? 
- b. Where will additional money come from?

- H. Will members be forced to participate, either by advancing more money, guarantees, or otherwise.

- a. What if members cannot agree on putting more money into company

- i. Secured loans from parties that want to contribute?

- ii. Procedure by which parties that want to contribute are able to buy-out parties that do not want to contribute

\section{Personal Commitment of Each Member}

- A. Nature, if any, of non-financial contribution by each member:

- B. Which members, if any, are to work in business?

- a. On what basis?

- C. How are responsibilities for business to be divided?

- D. How are member salaries/bonuses/commissions to be determined?Market rates and performance metrics-tied to performance and achieving milestones-mostly incentive in the beginning-reasonable salary with the majority of the compensation in incentives (either salary or equity)

- E. Any type of special covenants that will apply to each member while a member?

- a. e.g., non-competition, non-solicitation, ownership of any inventions?

- b. Trade secrets?

- F. Any type of special covenants that shall apply after member relationship terminates?

- e.g., non-competition, non-solicitation.

- G. Nature of activities to be restricted: (should include limits on cashing out early)

- H. Length of restriction in months or years:

- I. Geographic scope of restriction:

- J. Shall restrictions apply if relationship is terminated by company vs. member or "with cause" vs. "without cause"? If the termination is with cause then what equity can be cashed should be limited and more restrictions applied. If without cause and amicable, can get equity based on vesting schedule but also might be working for a customer not competitor and should be encouraged and relationship preserved

- K. Shall restrictions apply if company is no longer carrying on its business?

- L. Is any member currently subject to any limitations or special covenants from past or existing relationships arising out of equity ownership or employment? 


\section{Distribution of Profits}

- A. When are profits to be distributed and amount/percentage of same?

- a. By whom will the decisions be made?

- B. Are profits to be distributed based upon ownership of membership units or some other formula?

- C. What is procedure for determining timing and other distribution-related issues if member-decision-makers cannot agree?

- a. E.g., court, arbitration or mediation?

- b. Provisions in member agreement?

\section{Decision-Making Generally}

- A.By whom will decisions be made?

- Day-to-day

- Monthly review and large decisions

- Quarterly-Direction-setting and review

- B. Matter by which voting rights are to be handled.

- a. Simple majority vote vs. some other formula that involves a "super majority" or unanimity.

- C. What shall constitute a quorum of decision-makers

- a. e.g., majority of directors and members?

- b. Supermajority?

- c. Veto right on certain matters for one or more members?

- D. Describe any issues/items that shall require unanimous approval of all members (e.g.,admission of new members, sale of business):

- E. Of the issues/items set forth above, are there any members that would be willing to have resolved by arbitration or some other means in order to avoid a "deadlock"? - a. If so, what are they?

- F. Of the issues/items that require unanimous approval, are there any you would be willing to resolve by a super majority (e.g. approval by $2 / 3$ or $3 / 4$ of the members) in order to avoid a deadlock?

- G. Of the issues/items about which all members must agree, which of the following options, if any, do you favor for resolving deadlocks:

- a. Arbitration.

- b. Winding up of business.

- c. Sale of business with right of first refusal by each member. 
- d. Majority buys out minority.

- e. Some combination of the above.

\section{IX. "Getting Out" of the Company}

- A. Which of the following options do the members prefer if one or more wishes to "get out":

- a. Winding-up/dissolving the business.

- b. Selling the business with rights of first refusal for each non-departing member.

- c. Remaining members buy out departing member.

- d. Find a third-party buyer for membership units of departing member.

- e. Some combination of the above.

- B. In the event of a buy-out,

- a. How is purchase price to be determined?

$\circ$ b. How will the purchase price be paid?

- C. Any restrictions on "getting out"?

- a. Ability to "get out" within " $\mathrm{X}$ " years of incorporation.

- b. Ability to "get out" after specified period of years.

- D. Any "special" rules for certain members?

- a. Majority member.

- b. Next generation.

- c. Older generation.

- d. Venture capital or "angel" investor.

\section{X.“Forcing out” a Member}

- A. Under what circumstances may a member be forced-out, or in the case of a member-employee terminated?

- a. With or without cause?

- i. What constitutes "with cause"?

- ii. What about involuntary circumstances (e.g., death or disability)?

- B. By whom is "force-out" decision made?

- a. By what procedure (e.g. voting)?

- b. Board of Directors.

- c. Majority member.

- C. May a terminated member be forced to sell out or can he/she insist on being bought out? 
- a. Terms of sell-out/buy-out.

- b. How is purchase price determined?

- c. What are payment terms?

- d. Shall there be penalties for being terminated with cause? If so, - i. What are they?

- D. How does termination of member affect any non-competition and non-solicitation obligations he/she may have?

- a. Is answer the same if termination is "with cause" vs. "without cause"?

- E. What effect will "force-out" have on the company?

- a. Winding-up/dissolving the business.

- b. Selling the business with rights of first refusal for each non-departing member.

- c. Non-departing members buy-out departing member.

- d. Find a third-party buyer for departing member's membership units.

- e. Some combination of the above.

- F. In the event parting member is to be bought out:

- a. How is purchase price to be determined?

- b. What are the terms/conditions of payment?

- G. Any restrictions on "force-out"?

- a. "Force-out" not permitted within "X" years of incorporation.

- b. "Force-out" not permitted after " $\mathrm{X}$ " years of association with company.

- H. Any special rules for certain members?

- a. e.g., "Founding" members.

\section{XI.Majority/Minority Rights for "Selling Out"}

- A. Should each member have a right of first refusal in the event of a proposed sale of a company?

- B. Can the majority members force the minority members to sell to them

- a. If so, under what conditions, terms?

- C. Should the majority be able to force a sale of the entire company?

$\circ$ a. If so, under what terms?

- b. Would such proposed sale include a right or first refusal by the minority?

- c. Would such proposed sale include a provision whereby the minority would be forced to sell out on the same terms as the majority?

- $\mathrm{d}$. Should the minority be able to force any buyer who is purchasing a majority interest to purchase the minority interest at the same time and on the same terms? 


\section{Member in Default}

- A. In the event a member defaults on his/her obligations under the members' agreement,

- a. Should such default affect his/her right to receive a salary/bonus/commission.

- b. Should it affect his/her votes?

- c. Should it affect his/her right to participate in election or appointment of officers and/or directors?

- B. Should a "defaulting" member be forced-out from the company? If so,

- a. On what terms?

- i. Should these terms be more onerous than those that apply to a departing member who is not in default?

- C. What effect should forced buy-out have on the company?

- a. Winding-up/dissolving the company.

- b. Selling the company with rights of first refusal by each non-departing member.

- c. Non-defaulting members to (buy-out) defaulting member.

- d. Find a third-party-buyer for defaulting member's membership units.

- e. Some combination of the above.

- D. If non-defaulting members are to buy-out defaulting member then,

- a. How will buy-out price be determined?

- b. What will be the payment terms?

- c. Should defaulting member receive a "discounted" price because of his/her default?

\section{Disability of a Member}

- A. What to do if a member becomes sick or disabled for more than a specified period of time.

- B. How is the term "disability" to be defined?

- C. During the term of the disability, what will be the effect upon disabled member's - a. Salary.

- b. Profit membership unit.

- c. Membership unit ownership.

- D. How long should other members permit disability to persist before the disabled member is forced out/bought out?

- E. What effect does long term disability insurance payments have on considerations in $\mathrm{B}, \mathrm{C}$, and D immediately preceding and G below? 
- F. Options for force-out/buy-out include:

- a. Winding-up/dissolving the business.

- b. Selling the company with rights of first refusal for each non-disabled member.

- c. Non-disabled members buy-out disabled member.

- i. Equal division of disabled member's membership units among non-disabled members.

- d. Sale of disabled members' membership units to third-party-buyer.

- e. Some combination of the above.

- G. How is purchase price of disabled members membership units to be determined.

- a. What will be the payment terms?

\section{Death of a Member.}

- A. Does death trigger automatic buy-out of deceased member's membership units by company/surviving members?

- a. If not, can an estate of deceased member force the company to buy out deceased member's membership units?

- b. If death does not trigger an automatic buy-out, can membership units be left to spouse, children or others upon deceased member's death?

- B. Should any of the following options be triggered upon the death of one or more members:

- a. Winding up/dissolving the business.

- b. Selling the business with rights of first refusal for each surviving member?

- c. Finding a third-party buyer for membership units of deceased member(s).

- d. Some combination of the above?

- C. How are deceased member's membership units to be valued for buy-out purposes (i.e.how is purchase price to be calculated)?

- a. What are the payment terms?

\section{Loss of Control}

- A. What if a member loses control of his/her membership units through bankruptcy, divorce or some other event?

- B. How should such loss of control affect member's:

- a. Profit-sharing rights?

- b. Voting rights?

- c. Right to participate in election or appointment of officers and directors? 
- C. Does loss of control trigger a buy-out of member's membership units? If so,

- a. On what terms?

- i. Should these terms be more onerous than those that apply when a member is forced out or leaves company when in control of his/her membership units?

- D. Is loss of control an event of either "default" or otherwise that would trigger any of the following scenarios:

- a. Winding-up/dissolving the company?

- b. Selling the company with right of first refusal by each "non-defaulting" member?

- c. Non-defaulting members buying-out defaulting member?

- d. Finding a third-party buyer for defaulting member's membership units

- e. Some combination of the above.

- E. If loss of control is to trigger a buy-out by other members then,

- a. How is the purchase price to be determined?

$\circ$ b. What are the payment terms?

\section{Miscellaneous}

- A. Company's books and records.

- a. Equal access by all members?

- i. At all reasonable times? or

- ii. Some restriction?

- 1. e.g. only during normal business hours and/or with some type of advanced notice?

- 2. Limitation on types of books and records to be made available in specific circumstances?

- B. Confidentiality obligations.

- a. Generally, member relationship to be kept confidential to the extent practicable.

- b. Applicability after disposition of membership units by individual member.

- c. Exception: sale of business-dissemination of only "approved" materials after notice and consent by all/majority of members?

\section{- C. Use of Insurance to Fund Buy-out of Deceased/Disabled Member's} Membership units.

- a. Is buy-out to be funded with insurance?

- i. If so, how much insurance is to be purchased?

- 1. How is insurance to be updated?

- b. Who is to be the owner of the insurance policy? 
- i. The company?

- ii. The individual members?

- c. Who is to pay the insurance premiums?

- i. The company?

- ii. The individual members?

- d. What if a member is not insurable?

- i. Or is insurable, but not at "preferred" or "standard" rates?

- 1. Who should pay the cost of the premium in excess of "preferred"or "standard" rates?

- a. The company?

- b. The affected member?

- e. What if the cost of insurance or a particular policy is "too expensive"?

- f. What if the insurance claim is denied?

- g. What if the insurance money is insufficient to pay the entire cost of the buy-out price?

- $\mathrm{h}$. What if there is "excess" insurance money after the buy-out price is paid? - i. If no insurance, members may wish to pay buy-out price over time.

- i. What should the "time" payment terms be?

- j. Does each member prefer to assume responsibility for maintaining his/her own insurance with other members named as beneficiaries so there are funds to buyout membership units from deceased member's estate?; or Do they prefer a situation where company purchases the insurance and uses the insurance proceeds to buyout deceased member's membership units from his/her estate? 